\title{
MOLLUSKS ON RECRUITMENT PANELS PLACED IN AN OFFSHORE HARBOR IN TROPICAL NORTHEASTERN BRAZIL
}

\author{
Moluscos associados a placas de recrutamento instaladas \\ em um porto offshore no Nordeste Tropical Brasileiro
}

\author{
Cristiane Xerez Barroso', Soraya Guimarães Rabay², Helena Matthews-Cascon³ \\ ${ }^{1}$ Instituto de Ciências do Mar, Universidade Federal do Ceará, Av. Abolição, 3207, Meireles, Fortaleza, CEP 60.165-08, \\ CE, Brasil, Bolsista de Pós-Doutorado PNPD-CAPES, e-mail: cristianexb@gmail.com. \\ ${ }^{2}$ Laboratório de Invertebrados Marinhos, Departamento de Biologia, Centro de Ciências, Universidade Federal do Ceará, \\ Campus do Pici, Bloco 909, CEP 60455-760, Fortaleza, CE, Brasil; e-mail: sgrabay@yahoo.com.br. \\ ${ }^{3}$ Laboratório de Invertebrados Marinhos, Departamento de Biologia, Centro de Ciências, Universidade Federal do Ceará, \\ Campus do Pici, Bloco 909, CEP 60455-760, Fortaleza, CE, Brasil; e-mail: helenamc@gmail.com.
}

\begin{abstract}
In order to contribute to knowledge of marine fouling communities, the present study analyzed the temporal variation in molluscan communities found on quarterly and annual recruitment panels placed in a seaport area of northeastern Brazil. A set of 30 artificial panels was submerged among pier pillars to a depth of approximately $6 \mathrm{~m}$. Every three months, one subset of 15 panels was removed to examine the biota present. The second subset of 15 panels was left submerged for one year, and then removed for analysis. On the same day that the panels were removed, they were replaced with new panels. Twelve removals/replacements of panels were performed from October 2009 to November 2012. Two classes of Mollusca were found in the recruitment panels: Gastropoda and Bivalvia. Thirty taxa were found in the quarterly panels, and 23 taxa in the annual panels. Two non-native species of the Brazilian coast were found: Isognomon bicolor and Eualetes tulipa. In the quarterly panels, the most abundant and common species found was the oyster Crassostrea brasiliana and the most abundant species found in the annual panels was Musculus lateralis.
\end{abstract}

Keywords: artificial substrates; Bivalvia; Gastropoda; seaport area; temporal changes.

Recebido em: $15 / 07 / 2017$

Aprovado em: 05/02/2018

Publicado online em: 05/09/2018 


\section{RESUMO}

Como o objetivo de contribuir para o conhecimento das comunidades marinhas incrustantes, o presente estudo analisou a variação temporal em comunidades de moluscos encontradas em placas de recrutamento trimestrais e anuais instaladas em uma região portuária no nordeste do Brasil. Um conjunto de 30 placas artificiais foi submerso entre os pilares do pier a uma profundidade aproximada de $6 \mathrm{~m}$. A cada três meses, um subconjunto de 15 placas era removido para o exame da biota presente. O segundo subconjunto de 15 placas foi deixado submerso por um ano, e depois removido para análise. No mesmo dia em que as placas eram removidas, elas eram substituídas por novas placas. Doze remoções/reposições de placas foram realizadas de outubro de 2009 a novembro de 2012. Duas classes de Mollusca foram encontradas nos painéis de recrutamento: Gastropoda e Bivalvia. Trinta táxons foram encontrados nas placas trimestrais e 23 táxons nas placas anuais. Duas espécies nãonativas da costa brasileira foram encontradas: Isognomon bicolor e Eualetes tulipa. Nas placas trimestrais, a espécie mais comum e abundante foi a ostra Crassostrea brasiliana e a espécie mais abundante nas placas anuais foi o bivalve Musculus lateralis.

Palavras-chaves: substratos artificiais; Bivalvia; Gastropoda; área portuária; variações temporais.

\section{INTRODUCTION}

The structure and dynamic of a biological community cannot be understood without extensive knowledge of the ecology of the species belonging to the particular area of study. The structure of marine communities can be controlled by the supply of larvae and by the success of larval settlement, both of which are important factors in explaining species fluctuations in space and time (Lewis, 1964; Underwood, 1979; Moore \& Seed, 1986).

Pelagic larval life consists of three stages: the first is the developmental period where dispersion and feed may or may not occur; the second is the stage in which the substrate can be tested for possible settlement; and the third is the stage in which recruitment occurs (Underwood, 1979; Pechenik, 1999). A considerable variety of stimuli can be involved in the selection of the substrate on which the animal will settle. Responses to physical, chemical, and biochemical features, which attract the larvae to a particular habitat, are the factors that cause spatial variations in the number of larval settlements. Responses to physical, chemical, and biochemical stimuli from adults of their own species or related species result in a settlement of larvae in occupied or previously occupied areas (Underwood, 1978; 1986; Anderson \& Underwood, 1994).

The assemblage of invertebrate species comprising marine fouling communities occurs on artificial and natural substrates and is typically widespread (Karlson \& Osman, 2012). These communities are composed primarily of sessile, filter-feeding invertebrates and mobile epifauna such as ascidians, bryozoans, hydroids, sponges, crustaceans, and mollusks (Nydam \& Stachowicz, 2007). Artificial substrates, such as recruitment panels, are widely used to monitor marine fouling communities, describe spatial and temporal patterns and predator effects to determine the composition of the fouling community, and detect the presence of non-native species (e.g. Nydam \& Stachowicz, 2007; Broitman et al., 2008; Bumbeer \& Rocha, 2012; Fernandez et al., 2014; García-Sanz et al., 2014). 
In order to contribute to knowledge of marine fouling communities, the present study analyzed the temporal variation in molluscan communities found on the quarterly and annual recruitment panels placed in a seaport area of northeastern Brazil.

\section{MATERIALS AND METHODS}

Terminal Portuário do Pecém ( $\left.3^{\circ} 30^{\prime} \mathrm{S}, 39^{\circ} 50^{\prime} \mathrm{W}\right)$ is an offshore seaport, located on the west coast of Ceará in northeastern Brazil. A set of 30 sampling units (panels) was submerged among pillars of the pier at an approximately $6 \mathrm{~m}$ depth, consisting of two $10 \mathrm{x}$ $10 \mathrm{~cm}$ polyethylene plates arranged in parallel with a $2 \mathrm{~cm}$ gap between them.

Every three months, one subset of 15 panels was removed in order to examine the biota present. The second subset of 15 panels was left submerged for one year and then removed for analysis after that period. All removed panels were replaced by new ones on the same day as the removal of the old ones. Twelve removals/replacements of the panels were performed (twelve collections of the quarterly panels equaling 180 samples; three collections of the annual plates equaling 45 samples) from October 2009 to November 2012.

The samples were stored in labeled plastic bags and conserved in $70 \%$ ethanol. The mollusks were separated under a compound microscope and preserved in $70 \%$ ethanol. They were identified to the lowest possible taxonomic level using the appropriate references. It should be noted that empty shells were not considered in the analysis of this study.

All collected material was incorporated into the Malacological Collection "Prof. Henry Ramos Matthews" - series B of the Universidade Federal do Ceará (CMPHRM-B/UFC).

Geographical distribution, natural habitats, and feeding habits of the collected species were determined from a secondary database (e.g. Rios, 1994; 2009; Rosenberg et al., 2009).

\section{RESULTS}

\section{Species composition, abundance, and temporal frequency}

Two classes of Mollusca were found in the recruitment panels: Gastropoda (22 taxa) and Bivalvia (12 taxa). Fourteen taxa ( 2 bivalves and 12 gastropods) could not be identified at the species level due to their small size, as a result of being newly metamorphosed or very young individuals (Table I). Among the 20 species identified at specific levels, two are non-native species of the Brazilian coast - Isognomon bicolor (C. B. Adams, 1845) and Eualetes tulipa (Rousseau in Chenu, 1843).

Thirty taxa were found in the quarterly panels (eight with temporal frequency above $50 \%$ ) and 23 taxa in the annual panels (11 with temporal frequency above $50 \%$ ) (Table I). Of 34 taxa found, 19 (55.88\%) occurred in both the quarterly and the annual samples, 11 $(32.35 \%)$ were only recorded in the quarterly panels, and four $(11.77 \%)$ were exclusive to the annual plates (Table I).

In the quarterly panels, the most abundant and common species was the oyster Crassostrea brasiliana (Lamarck, 1819) (1,700 specimens; 100\% temporal frequency). However, this species was only the fifth most abundant species in the annual plates (54 individuals; $100 \%$ temporal frequency). The second most abundant species in the quarterly plates was the bivalve Musculus lateralis (Say, 1822) (1,482 specimens; $100 \%$ temporal frequency). Musculus lateralis was also the most abundant species in the annual panels (1,237 specimens; $100 \%$ temporal frequency). Gastropods of the family Columbellidae 
[Anachis veleda (Duclos, 1846), Anachis isabellei (d'Orbigny, 1839), and Mitrella pusilla (Sowerby, 1844)] were also common species in the quarterly and annual plates (Table I).

Regarding the non-native species, six specimens of I. bicolor occurred in the recruitment panels (five in the quarterly plates and one in the annual plates), and five specimens of Eualetes tulipa were found in the annual plates (Table I).

Table I - Molluscan species recorded on recruitment panels placed in the offshore harbor at Terminal Portuário do Pecém (NE Brazil) from October 2009 to November 2012; their respective abundance and temporal frequencies on 3-month and 1-year samples.

\begin{tabular}{|c|c|c|c|c|}
\hline \multirow[b]{2}{*}{ Class/Species } & \multicolumn{2}{|c|}{ Quarterly panels } & \multicolumn{2}{|c|}{ Annual panels } \\
\hline & $\begin{array}{c}\text { Total } \\
\text { abundance }\end{array}$ & $\begin{array}{c}\text { Temporal } \\
\text { frequency } \\
(n=12)\end{array}$ & $\begin{array}{c}\text { Total } \\
\text { abundance }\end{array}$ & $\begin{array}{c}\text { Temporal } \\
\text { frequency } \\
(n=3)\end{array}$ \\
\hline Bivalvia & 3,427 & $100 \%$ & 1,511 & $100 \%$ \\
\hline Crassostrea brasiliana (Lamarck, 1819) & 1,700 & $100 \%$ & 54 & $100 \%$ \\
\hline Musculus lateralis (Say, 1822) & 1,482 & $100 \%$ & 1,237 & $100 \%$ \\
\hline Sphenia fragilis (H. Adams \& A. Adams, 1854) & 112 & $67 \%$ & 150 & $100 \%$ \\
\hline Chlamys sp. & 41 & $58 \%$ & 35 & $67 \%$ \\
\hline Diplodonta nucleiformis (W. Wagner, 1840) & 39 & $17 \%$ & 3 & $67 \%$ \\
\hline Diplodonta punctata (Say, 1822) ${ }^{\mathrm{a}}$ & 17 & $25 \%$ & & \\
\hline Arca imbricata Bruguière, 1789 & 17 & $25 \%$ & 16 & $67 \%$ \\
\hline Entodesma brasiliense (Gould, 1850) & 8 & $8 \%$ & 10 & $33 \%$ \\
\hline Isognomon bicolor (C. B. Adams, 1845) & 5 & $17 \%$ & 1 & $33 \%$ \\
\hline Pinctada imbricata Röding, 1798 & 3 & $25 \%$ & 4 & $33 \%$ \\
\hline Pteria hirundo (Linnaeus, 1758) ${ }^{\mathrm{a}}$ & 3 & $17 \%$ & & \\
\hline Chama sp. ${ }^{a}$ & & & 1 & $33 \%$ \\
\hline Gastropoda & 716 & $100 \%$ & 339 & $100 \%$ \\
\hline Mitrella pusilla (Sowerby, 1844) & 342 & $83 \%$ & 63 & $67 \%$ \\
\hline Anachis isabellei (d'Orbigny, 1839) & 127 & $58 \%$ & 17 & $33 \%$ \\
\hline Anachis veleda (Duclos, 1846) & 122 & $83 \%$ & 36 & $100 \%$ \\
\hline Caecum sp. & 61 & $75 \%$ & 123 & $100 \%$ \\
\hline $\begin{array}{l}\text { Marionia limceana Silva, Meirelles \& Matthews- } \\
\text { Cascon, } 2013\end{array}$ & 16 & $42 \%$ & 5 & $33 \%$ \\
\hline Turbonilla sp. & 9 & $33 \%$ & 6 & $67 \%$ \\
\hline Lamellaria sp. ${ }^{\mathrm{a}}$ & 8 & $33 \%$ & & \\
\hline Vitreolina arcuata (C. B. Adams, 1850) & 6 & $8 \%$ & 1 & $33 \%$ \\
\hline Fissurella sp. & 4 & $8 \%$ & 3 & $33 \%$ \\
\hline Cyclostremiscus sp. & 3 & $8 \%$ & 40 & $67 \%$ \\
\hline Aeolidiidae species $1^{\mathrm{a}}$ & 3 & $8 \%$ & & \\
\hline Astraea sp. ${ }^{\mathrm{a}}$ & 2 & $8 \%$ & & \\
\hline Cymatium sp. ${ }^{\mathrm{a}}$ & 2 & $8 \%$ & & \\
\hline Bittiolum varium (Pfeiffer, 1840$)^{a}$ & 2 & $8 \%$ & & \\
\hline Crepidula sp. ${ }^{\mathrm{a}}$ & 2 & $8 \%$ & & \\
\hline Luria cinerea (Gmelin, 1791) ${ }^{\mathrm{a}}$ & 1 & $8 \%$ & & \\
\hline $\begin{array}{l}\text { Stramonita brasiliensis Claremont \& D. G. Reid, } \\
2011^{\text {a }}\end{array}$ & 1 & $8 \%$ & & \\
\hline Facelinidae species $1^{\mathrm{a}}$ & 1 & $8 \%$ & & \\
\hline Haminoea elegans (Gray, 1825) & 1 & $8 \%$ & 13 & $33 \%$ \\
\hline Doto sp. ${ }^{\mathrm{a}}$ & & & 21 & $33 \%$ \\
\hline Diodora sp. ${ }^{\text {a }}$ & & & 4 & $33 \%$ \\
\hline Eualetes tulipa (Rousseau in Chenu, 1843) ${ }^{\text {a }}$ & & & 5 & $33 \%$ \\
\hline
\end{tabular}

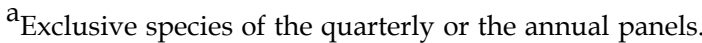




\section{Ecological and geographical data of species}

Among gastropods, the most representative feeding habit was carnivore (10 species), followed by grazer (5), herbivore (3), parasitic (2), and suspension feeder (2) (Table II). All bivalves found are filter feeders.

All individuals identified at the species level were previously reported on the coast of Ceará (Table III).

Table II - Gastropod species recorded from October 2009 to November 2012 at Terminal Portuário do Pecém (NE Brazil) and their respective feeding habits.

\begin{tabular}{ll}
\hline Species & Feeding habits \\
\hline Anachis veleda, Anachis isabellei, Mitrella pusilla, Lamellaria sp., Cymatium sp., Stramonita & Carnivore \\
brasiliensis, Marionia limceana, Doto sp., Aeolidiidae species 1, Facelinidae species 1 & Grazer \\
Luria cinerea, Bittiolum varium, Caecum sp., Cyclostremiscus sp., Haminoea elegans & Herbivore \\
Diodora sp., Fissurella sp., Astraea sp. & Parasitic \\
Turbonilla sp., Vitreolina arcuata & Suspension feeder \\
Eualetes tulipa, Crepidula sp. &
\end{tabular}

Table III - Geographical distribution and natural habitats of molluscan species recorded on recruitment panels placed in the offshore harbor at Terminal Portuário do Pecém (NE Brazil) from October 2009 to November 2012. Legend: *Non-native species.

\begin{tabular}{|c|c|c|}
\hline Class/Species & Geographical distribution & Natural habitats \\
\hline \multicolumn{3}{|l|}{ Bivalvia } \\
\hline Crassostrea brasiliana (Lamarck, 1819) & Brazil (Ceará to Santa Catarina) $^{a}$ & $\begin{array}{l}\text { rocky coasts and } \\
\text { mangroves }^{\mathrm{a}}\end{array}$ \\
\hline Musculus lateralis (Say, 1822) & $\begin{array}{l}\text { N. Carolina to Florida, Texas, Mexico, } \\
\text { Caribbean to Brazil (Ceará, Pernambuco to } \\
\text { Santa Catarina; Trindade Is.) } \text { (b, }^{\text {b }}\end{array}$ & host of ascidians ${ }^{\mathrm{b}, \mathrm{d}}$ \\
\hline $\begin{array}{l}\text { Sphenia fragilis (H. Adams \& A. Adams, } \\
\text { 1854) }\end{array}$ & $\begin{array}{l}\text { Texas, Puerto Rico, Surinam, Brazil (Ceará } \\
\text { to Santa Catarina) }\end{array}$ & $\begin{array}{l}\text { worn burrows, oyster } \\
\text { and mussel colonies }{ }^{\mathrm{b}}\end{array}$ \\
\hline Diplodonta nucleiformis (W. Wagner, 1840) & N. Carolina to Florida, Caribbean, Brazil ${ }^{\mathrm{b}}$ & $\begin{array}{l}\text { sandy and coral } \\
\text { substrates }^{\mathrm{b}}\end{array}$ \\
\hline Diplodonta punctata (Say, 1822) & $\begin{array}{l}\text { Bermuda, N. Carolina to Florida, Caribbean, } \\
\text { Brazil (Amapá to São Paulo, Fernando de } \\
\text { Noronha) to Magellanic Region and Chiloé } \\
\text { Is. (Chile) })^{\text {b,e }}\end{array}$ & $\begin{array}{l}\text { sandy and mud-sandy } \\
\text { bottoms }{ }^{\mathrm{e}}\end{array}$ \\
\hline Arca imbricata Bruguière, 1789 & $\begin{array}{l}\text { N. Carolina to Florida, Texas, Caribbean, } \\
\text { Venezuela, Surinam, Brazil (Pará to Santa } \\
\text { Catarina, Fernando de Noronha) }\end{array}$ & rocks and corals ${ }^{\mathrm{b}}$ \\
\hline Entodesma brasiliense (Gould, 1850) & $\begin{array}{l}\text { Bermuda, N. Carolina to Florida, Caribbean, } \\
\text { Brazil (Amapá to Rio de Janeiro) }{ }^{\mathrm{b}}\end{array}$ & sponges and tunicates $^{\mathrm{b}}$ \\
\hline Pinctada imbricata Röding, 1798 & $\begin{array}{l}\text { Bermuda, N. Carolina to Florida, Texas, } \\
\text { Caribbean, Venezuela, Brazil (Pará to Santa } \\
\text { Catarina) }\end{array}$ & $\begin{array}{l}\text { rocks, corals, and } \\
\text { mangrove roots }{ }^{2}\end{array}$ \\
\hline Pteria hirundo (Linnaeus, 1758) & $\begin{array}{l}\text { Bermuda, N. Carolina to Florida, Texas, } \\
\text { Caribbean, Venezuela, all Brazilian coast }{ }^{\mathrm{b}}\end{array}$ & $\begin{array}{l}\text { gorgonians, buoys and } \\
\text { dead shells }{ }^{\mathrm{b}}\end{array}$ \\
\hline Isognomon bicolor (C. B. Adams, 1845)* & $\begin{array}{l}\text { Bermuda, Florida to Texas, Caribbean, } \\
\text { Venezuela, Brazil (Piauí to Santa Catarina; } \\
\text { Atol das Rocas) })^{b, f, g, h, i}\end{array}$ & $\begin{array}{l}\text { rocks, corals, calcareous } \\
\text { algae and magrove } \\
\text { roots }^{b, f, g, h, i}\end{array}$ \\
\hline \multicolumn{3}{|l|}{ Gastropoda } \\
\hline Mitrella pusilla (Sowerby, 1844) & $\begin{array}{l}\text { Bermuda, N. Carolina to Florida, Texas, } \\
\text { Caribbean, Brazil (Ceará to Santa Catarina, } \\
\text { Abrolhos Is., Vitória Seamount) }\end{array}$ & sand, Sargassum weeds ${ }^{b}$ \\
\hline Anachis isabellei (d'Orbigny, 1839) & $\begin{array}{l}\text { Brazil (NE Brazil and Rio Grande do Sul) to } \\
\text { Argentina (Golfo S. Matias) }\end{array}$ & sandy bottoms ${ }^{\mathrm{b}}$ \\
\hline Anachis veleda (Duclos, 1846) & $\begin{array}{l}\text { Costa Rica to Panamá, Cuba, Central } \\
\text { America to Brazil (Ceará to Santa Catarina) }\end{array}$ & under rocks near algae ${ }^{b}$ \\
\hline $\begin{array}{l}\text { Marionia limceana Silva, Meirelles \& } \\
\text { Matthews-Cascon, } 2013\end{array}$ & $\begin{array}{l}\text { Ceará to Rio Grande do Norte (northeast } \\
\text { Brazil) }\end{array}$ & octocorals ${ }^{\mathrm{j}}$ \\
\hline
\end{tabular}


(continuation of Table III)

Vitreolina arcuata (C. B. Adams, 1850)

Bittiolum varium (Pfeiffer, 1840)

Luria cinerea (Gmelin, 1791)

Stramonita brasiliensis Claremont \& D. G. Reid, 2011

Haminoea elegans (Gray, 1825)

Eualetes tulipa (Rousseau in Chenu, 1843) *
N. Carolina to Florida, Texas, Jamaica, Brazil (Ceará, São Paulo to Rio Grande do Sul) $)^{b, c}$

N. Carolina to Florida, Texas, Caribbean, all Brazilian coast ${ }^{\mathrm{b}}$

Bermuda, N. Carolina to Florida, Caribbean, Northern South America, Brazil (Amapá to

Cabo Frio - RJ, Atol das Rocas, Fernando de Noronha Is., Abrolhos, Trindade Is. and seamounts), Ascension Is. ${ }^{b}$

Lesser

Antilles (Trinidad, Tobago, Dominica, St. Thomas), Venezuela to Uruguay, Fernando de Noronha and Trindade Is. ${ }^{k}$

Mediterranean Sea, Portugal, Marocco, Sta.

Helena Is., N. Bermuda, Florida, Texas, Caribbean, Brazilian coast (Ceará, Alagoas to Santa Catarina) ${ }^{\mathrm{b}, \mathrm{l}}$

Florida, Costa Rica, Panama, Hawaii, Venezuelan Caribbean, Brazil (Ceará, Rio

Grande do Norte, and Rio de Janeiro); India $^{\mathrm{m}}$ ectoparasitic on

echinoderms ${ }^{\mathrm{b}}$

algae, marine grass ${ }^{b}$

sand, rocks and coral

reefs $^{b}$

rocky shores ${ }^{k}$

muddy bottoms ${ }^{b}$

artificial (monobuoys, breakwaters, pillars, and offshore port) or natural (rocky reefs) substrates ${ }^{\mathrm{m}}$

References: aAmaral \& Simone (2014); ${ }^{\text {DRios }}$ (1994; 2009); 'Veras et al. (2013); ${ }^{\mathrm{d} C a n ̃ e t e ~ \& ~ R o c h a ~(2013) ; ~}{ }^{\text {Domaneschi }}$ (1979); ${ }^{\mathrm{C}}$ Domaneschi \& Martins (2002); ${ }^{\mathrm{F}}$ Franklin-Jr. et al. (2005); hLoebmann et al. (2010); ${ }^{\mathrm{h}} \mathrm{Dias}$ et al. (2013); iSilva et al.

(2013); ' Claremont et al. (2011); 'Galvão-Filho et al. (2015); 'mSpotorno-Oliveira et al. (2017).

\section{DISCUSSION}

The richness of mollusks, the number of newly metamorphosed or very young individuals, and the variety of feeding habits found in this study show that the recruitment panels provide a microhabitat able to support different trophic guilds. Research using these same recruitment panels, conducted by Paiva (2013) and Fernandez et al. (2015), reinforce the evident richness of this habitat. Paiva (2013) found great coverage percentages of ascidians and bryozoans, as well as other groups, such as polychaete worms, sponges, hydroids, bivalves, octocorals, barnacles, and anemones. Also, Fernandez et al. (2015) studied the temporal patterns in richness and composition of benthic cnidarian assemblage.

The majority of gastropods found are mobile or semi-sessile organisms, and their presences are due to the availability of food in the recruitment panels. Columbellidae is a very diverse family and contains species that are either herbivorous or carnivorous (Marcus \& Marcus, 1962; Bandeira et al., 2014). The representative abundance of Columbellidae, as well as the considerable number of carnivorous species, found in the recruitment panels maybe due to the presence of sessile animals such as tunicates and sponges that are their prey. The parasitic gastropod Turbonilla sp. belongs to the Pyramidelloidea, comprising the ectoparasites of bivalves and polychaetes (Rios, 1994), while Vitreolina arcuata belongs to Eulimidae, a family of very small parasitic sea snails in echinoderms and other marine animals (Warén, 1992; Rios, 1994).

On the other hand, the great number of bivalve taxa found is related to the different strategies allowing them to inhabit the recruitment panels. Isognomon bicolor, Pinctada imbricata, Pteria hirundo, Chlamys sp., and Arca imbricata have a byssus (a bundle of proteinaceous filaments secreted by a gland on the foot), which allows them to colonize hard surfaces. The remaining species of bivalves directly settled on the recruitment panels 
(e.g., Crassostrea brasiliana) or drilled into the fouling animals (mainly ascidians) to settle (e.g., Musculus lateralis, Diplodonta nucleiformis, Diplodonta punctata, Sphenia fragilis, and Entodesma brasiliense).

The great abundance of Musculus lateralis, found in this study, can be explained by the high coverage percentage of its hosts (ascidians) on the recruitment panels. Cañete \& Rocha (2013) also reported this interaction between M. lateralis and ascidians. Another species commonly found in tunicates as well as sponges, Entodesma brasiliense, was also found in this study (Rios, 1994).

Throughout the study, it was observed that the oyster C. brasiliana settled in the recruitment panels, and over time, was covered by other fouling organisms, especially ascidians. This recoating caused the death of these bivalves. Several covered shells were found in the annual plates, but they were not counted due to they were no longer alive at the time of collection (only shells existed with no soft tissue). This may explain the greater abundance of $C$. brasiliana in the quarterly plates than in the annual ones.

The presence of I. bicolor, one of the non-native species found in this study, is well documented in Brazil (Breves-Ramos et al., 2010; Dias et al., 2013). This is an invasive species found in hard substrates all along the Brazilian coast; it was originally distributed in the Caribbean (Domaneschi \& Martins, 2002; Dias et al., 2013). Domaneschi \& Martins (2002) believe that the arrival of this species in Brazil occurred between 1970 and 1980 because previous malacological surveys did not record the presence of I. bicolor on the Brazilian coast. The first records of I. bicolor in the intertidal rocky shore of the coast of Ceará were made by Franklin-Jr. et al. (2005) on eight beaches, including Pecém Beach, where Terminal Portuário do Pecém is located.

Spotorno-Oliveira et al. (2017) just recently confirmed the presence of Eualetes tulipa in the Brazilian coast. These authors discuss the first documented occurrence of this species in Brazil, which was in 2005 at Ceará State (NE), and its register in the Rio de Janeiro (SE) four years later. The impact on the native benthic community of Brazilian coast is still unknown, but Spotorno-Oliveira et al. (2017) found E. tulipa growing on artificial substrates and also on sandstone fringing reefs and rocky reefs, coexisting with the native species Petaloconchus varians (d'Orbigny, 1839).

The record of only two species of non-native molluscs in this study may be related to the offshore location of the Terminal Portuário do Pecém. Wasson et al. (2005) carried out a marine invasion investigation of central California, and their results revealed that the absolute number of exotic species in the estuary was an order of magnitude higher than that along the open coast. According to them, possible reasons for this were differential transport processes between the two types of marine habitats, numbers of propagules (introduction rates), retention rates, and resistance due to the markedly greater species richness of open coast versus estuaries. Bumbeer \& Rocha (2012) reported the presence of nine introduced species out of a total of 40 in an area on the inner continental shelf under the influence of the large estuarine complex. Among explanations given by the authors for their detection were the influence of the nearby estuary with an international port where most of the introduced species had been reported and the proximity of the study area to the route of ships entering the port.

The placement of recruitment panels was shown to be an efficient methodology for the study of mollusk species recruitment. This reinforces their role in the monitoring of port areas. 
Acknowledgements - This experiment was part of the project “Bentos em regiões portuárias ao longo da Costa Brasileira: biodiversidade, filogeografia e aspectos de bioinvasão por biofouling," done in partnership with the Universidade Federal do Ceará, the Universidade Federal do Paraná, and the Universidade de São Paulo. The authors thank to Coordenação de Aperfeiçoamento de Pessoal de Nível Superior (Capes) for the financial support. The authors also thank people who helped in fieldwork and laboratory procedures, especially Amarílis B. Paiva.

\section{REFERENCES}

Amaral, V.S. \& Simone, L.R.L. Revision of genus Crassostrea (Bivalvia: Ostreidae) of Brazil. J. Mar. Biol. Assoc. UK, Londres, v.94, p.811-836, 2014.

Anderson, M.J. \& Underwood, A.J. Effects of substratum on the recruitment and development of an intertidal estuarine fouling assemblage. J. Exp. Mar. Biol. Ecol., Amsterdam, v.184, p.217-236, 1994.

Bandeira, E.V.P.; Rabay, S.G. \& Matthews-Cascon, H. Sexually dimorphic radular morphology in Columbella mercatoria (Mollusca: Gastropoda: Columbellidae). Arq. Ciênc. Mar, Fortaleza, v.47, p.78-82, 2014.

Breves-Ramos, A.; Junqueira, A.O.R; Lavrado, H.P.; Silva, S.H.G. \& Ferreira-Silva, M.A.G. Popopulation structure of the invasive bivalve Isognomon bicolor on rocks shores of Rio de Janeiro State (Brazil). J. Mar. Biol. Assoc. UK, Londres, v.90, p.453-459, 2010.

Broitman, B.R.; Blanchette, C.A.; Menge, B.A.; Lubchenco, J.; Krenz, C.; Foley, M.; Raimondi, P.T.; Lohse, D. \& Gaines, S.D. Spatial and temporal patterns of invertebrate recruitment along the west coast of the United States. Ecol. Monogr., Washington DC, v.78, p.403-421, 2008.

Bumbeer, J.A. \& Rocha, R.M. Detection of introduced sessile species on the near shore continental shelf in southern Brazil. Zoologia, Curitiba, v.29, n.2, p.126-134, 2012.

Cañete, J.I. \& Rocha, R.M. Modiolarca lateralis (Pteryomorphia: Mytilidae): bivalve associated to six species of ascidians from Bocas del Toro, Panama. Latin Am. J. Aquat. Res., Valparaíso, v.41, p.1030-1035, 2013.

Claremont, M.; Williams, S.T.; Barraclough, T.G. \& Reid, D.G. The geographic scale of speciation in a marine snail with high dispersal potential. J. Biogeogr., Medford, v.38, p.1016-1032, 2011.

Dias, T.L.P.; Mota, E.L.S.; Gondim, A.I.; Oliveira, J.M.; Rabelo, E.F.; Almeida, S.M. \& Christoffersen, M.L. Isognomon bicolor (C.B. Adams, 1845) (Mollusca: Bivalvia): First record of this invasive species for the State of Paraíba and Alagoas and new records fot other localities of Northeastern Brazil. Check List, São Paulo, v.9, p.157-161, 2013.

Domaneschi, O. Aspectos da biologia de Diplodonta punctata (Say, 1822) (Bivalvia Lucinacea - Ungulinidae). Rev. Nord. Biol., João Pessoa, v.2, p.21-25, 1979.

Domaneschi, O. \& Martins, C.M. Isognomon bicolor (C.B. Adams) (Bivalvia, Isognomonidae): primeiro registro para o Brasil, redescrição da espécie e considerações 
sobre a ocorrência e distribuição de Isognomon na costa brasileira. Rev. Bras. Zool., Curitiba, v.19, p.611-627, 2002.

Fernandez, M.O.; Navarrete, S.A. \& Marques, A.C. Temporal variation in richness and composition of recruits in a diverse cnidarian assemblage of subtropical Brazil. J. Exp. Mar. Biol. Ecol., Amsterdam, v.460, p.144-152, 2014.

Fernandez, M.O.; Navarrete, S.A. \& Marques, A.C. A comparison of temporal turnover of species from benthic cnidarian assemblages in tropical and subtropical harbours. Mar. Biol. Res., Norway, v.11, p.492-503, 2015.

Franklin-Jr., W.; Matthews-Cascon, H.; Bezerra, L.E.A.; Meirelles, C.A.O. \& Soares, M.O. Macrofauna bentônica de ambientes consolidados no Estado do Ceará - região entremarés de praias rochosas. Relatório Científico do Projeto de Zoneamento Ecológico Econômico do Litoral do Ceará - ZEE, SEMACE/FCPC/LABOMAR-UFC, 111p., Fortaleza, 2005.

Galvão-Filho, H.C.; Araújo, A.K.; Silva, F.V.; Azevedo, V.M.D.; Meirelles, C.A.O. \& Matthews-Cascon, H. Sea slugs (Gastropoda: Heterobranchia) from a poorly known area in North-east Brazil: filling gaps in Atlantic distributions. Mar. Biodiv. Rec., Londres, v.8, p.e115, 2015.

García-Sanz, S.; Navarro, P.G. \& Tuya, F. Colonization of prosobranch gastropods onto artificial substrates: seasonal patterns between habitat patches. Am. Malacol. Bull., Washington DC, v.32, p.94-103, 2014.

Karlson, R.H. \& Osman, R.W. Species composition and geographic distribution of invertebrates in fouling communities along the east coast of the USA: a regional perspective. Mar. Ecol. Prog. Ser., Amsterdam, v.458, p.255-268, 2012.

Lewis, J.R. The ecology of rocky shores. The English Universities Press LTD, XII + 323p., Londres, 1964.

Loebmann, D.; Mai, A.C. \& Lee, J.T. The invasion of five alien species in the Delta do Parnaíba Environmental Protection Area, Northeastern Brazil. Rev. Biol. Trop., San José, v.58, p.909-923, 2010.

Marcus, E. \& Marcus, E. Studies on Columbellidae. Bol. Univ. São Paulo., São Paulo, v.261, p.335-402, 1962.

Moore, P.G. \& Seed, R. The ecology of rocky coasts. Columbia University Press, 467p., New York, 1986.

Nydam, M. \& Stachowicz, J.J. Predator effects on fouling community development. Mar. Ecol. Prog. Ser., Amsterdam, v.337, p.93-101, 2007.

Paiva, A.B. Estudo comparativo das assembleias de ascídias em duas regiões portuárias da costa brasileira. Dissertação de Mestrado, Programa de Pós-Graduação em Ciências marinhas Tropicais, Universidade Federal do Ceará, 87p., Fortaleza, 2013.

Pechenik, J.A. On the advantages and disadvantages of larval stages in benthic marine invertebrate life cycle. Mar. Ecol. Prog. Ser., Amsterdam, v.177, p.269-297, 1999.

Rios, E.C. Seashells of Brazil, 2a . ed., Fundação da Universidade do Rio Grande, 481p., Rio Grande, 1994.

Rios, E.C. Compendium of Brazilian Sea Shells. Editora Evangraf, 720p., Rio Grande, 2009. 
Rosenberg, G.; Moretzsohn, F. \& García, E.F. Gastropoda (Mollusca) of the Gulf of Mexico, p.579-700, in: Felder, D.L. \& Camp, D.K. (eds.), Gulf of Mexico: origin, waters, and biota - vol. 1, Biodiversity. Texas A\&M University Press, 393p., Texas, 2009.

Silva, F.V.; Meirelles, C.A.O. \& Matthews-Cascon, H. A new species of Marionia (Opisthobranchia: Nudibranchia: Tritoniidae) from the tropical South Atlantic Ocean. J. Mar. Biol. Assoc. UK, Londres, v.93, p.1617-1624, 2013.

Spotorno-Oliveira, P.; Coutinho, R. \& Tâmega, F.T.S. Recent introduction of non-indigenous vermetid species (Mollusca, Vermetidae) to the Brazilian coast. Mar. Biodiv., Londres, doi:10.1007/s12526-017-0702-7, 2017.

Underwood, A.J. A refutation of critical tidal levels as determinants of the structure of intertidal communities on british shores. J. Exp. Mar. Biol. Ecol., Amsterdam, v.33, p.261-276, 1978.

Underwood, A.J. The ecology of intertidal gastropods. Adv. Mar. Biol., Flórida, v.16, p.11210, 1979.

Underwood, A.J. Physical factors and biological interactions: the necessity and nature of ecological experiments, p.372-373, in Moore, P.G. \& Seed, R. (eds.), The Ecology of Rocky Coasts. Columbia University Press, 467p., New York, 1986.

Veras, D.R.A.; Martins, I.X. \& Matthews-Cascon, H. Mollusks: How are they arranged in the rocky intertidal zone? Iheringia, Ser. Zool., Porto Alegre, v.103, p.97-103, 2013.

Warén, A. Comments on and descriptions of eulimid gastropods from Tropical West America. The Veliger, Berkeley, v.35, p.177-194, 1992.

Wasson, K.; Fenn, K. \& Pearse, J.S. Habitat differences in marine invasions of central California. Biol. Invasions, Knoxville, v.7, p.935-948, 2005. 